\title{
Exploring entomopathogenic fungi from South Sumatra (Indonesia) soil and their pathogenicity against a new invasive maize pest, Spodoptera frugiperda
}

\author{
SITI HERLINDA ${ }^{1,2, \vartheta}$, NONI OCTARIATI ${ }^{1}$, SUWANDI SUWANDI $^{1,2}$, HASBI $^{2,3}$ \\ ${ }^{1}$ Department of Plant Pests and Diseases, Faculty of Agriculture, Universitas Sriwijaya. Jl. Raya Palembang-Prabumulih Km 32, Indralaya, Ogan Ilir \\ 30662, South Sumatra, Indonesia. Tel.: +62-711-580663, Fax.: +62-711-580276, "email: sitiherlinda@unsri.ac.id \\ ${ }^{2}$ Research Center for Sub-optimal Lands (PUR-PLSO), Universitas Sriwijaya. Jl. Padang Selasa No. 524, Bukit Besar, Palembang 30139, South Sumatra, \\ Indonesia \\ ${ }^{3}$ Agricultural Engineering Program, Faculty of Agriculture, Universitas Sriwijaya. Jl. Raya Palembang-Prabumulih, Km 32, Indralaya, Ogan Ilir 30662 , \\ South Sumatra, Indonesia
}

Manuscript received: 14 April 2020. Revision accepted: 8 June 2020.

\begin{abstract}
Herlinda S, Octariati N, Suwandi S, Hasbi. 2020. Exploring entomopathogenic fungi from South Sumatra (Indonesia) soil and their pathogenicity against a new invasive maize pest, Spodoptera frugiperda. Biodiversitas 21: 2955-2965. Fall armyworm (Spodoptera frugiperda) is a new invasive maize pest in Indonesia that can cause maize yield losses of 18 million tons/year. To overcome the pest, local-specific entomopathogenic fungi are needed. This study aimed to explore entomopathogenic fungi from soil in South Sumatra and to determine their pathogenicity against $S$. frugiperda larvae. The fungi exploration was carried out in the lowlands and highlands of South Sumatra and the pathogenicity of obtained isolates were tested against the third instar larvae. The entomopathogenic fungi found were Metarhizium spp. and were successfully isolated as many as 14 isolates. All of the isolates were pathogenic to $S$. frugiperda larvae (70.67-78.67\% mortality), the most pathogenic caused $78.67 \%$ mortality and significantly suppressed the emergence of adults up to $81.2 \%$. Unhealthy larvae had a dry, shrunken, shrinking, odorless body, and its integument was covered in mycelia and conidia like yellowish-white powdery mixed with dark green. The unhealthy pupae and adults were in the abnormal and malformation shape. The abnormal pupae were shorter in size, bent, the to-be wings got wrinkled, and darker color, while the unhealthy adults had folded wings and were unable to fly. The two most pathogenic isolates were found from the lowland (PirOI) and highland (CasPsPGA) soil of South Sumatra. In conclusion, both of these isolates had the potential to be developed into local-specific mycoinsecticides to control pest insects in the highlands and/or lowlands in Indonesia.
\end{abstract}

Keywords: Fall armyworm, isolate, larvae, Metarhizium, pupae

\section{INTRODUCTION}

Currently, the maize (Zea may) in Indonesia is under severe invasion by a new invasive pest called the fall armyworm (FAW) with the scientific name Spodoptera frugiperda (Lepidoptera: Noctuidae). The S. frugiperda originally comes from South America (Nagoshi et al. 2017; Otim et al. 2018) and now this pest has spread to various continents. In 2016, the FAW was reported to have entered Africa (Goergen et al. 2016). In 2017, the FAW spread into Europe (Early et al. 2018). The pest began to enter Asia in 2018 and was first discovered in India (Ganiger et al. 2018). In April 2019, the FAW reportedly began entering Indonesia and was first discovered in West Sumatra, after which it spread throughout Sumatra, including Lampung (Lestari et al. 2020) and Palembang. Then, the pest crossed to Java and Kalimantan (IPPC 2019).

Maize attacked by $S$. frugiperda larvae generally suffered very heavy damage. In 2016, the maize yield loss in 12 African countries reached 18 million tons/year and the value of losses reached US \$ 13 millions (Harrison et al. 2019). In 2018, the FAW caused losses of about a third of the annual production maize in Kenya, estimated at about 1 million tons/year (De Groote et al. 2020). The pest was also reported to attack rice, sugar cane, cotton, and ornamental plants (IPPC 2019). In Brazil, around 76 plant families were reported to be attacked by the pest (Montezano et al. 2018). The outbreaks of FAW moth in maize was influenced by the growth stage of the crop, rainfall, and relative humidity (Nboyine et al. 2020). From the initial survey in South Sumatra, it was found that the $S$. frugiperda larvae attacked leaves, stems, flowers, fruits, and growth points to the whole maize stalk. The $S$. frugiperda becomes a new invasive pest in Indonesia because of the ideal ecosystem for its growth and development.

In Indonesia, S. frugiperda is controlled by synthetic insecticides and farmers in various countries in the world rely heavily on synthetic insecticides (Kumela et al. 2018). However, the more often sprayed with the synthetic insecticides, the FAW invasion is increasingly widespread and severe and until March 2020 we have been getting the sweet maize in various agriculture centers in South Sumatra destroyed by the pest. This is because the pest has been resistant to various active ingredients of synthetic insecticides (Wu et al. 2016; Yang et al. 2017). For this reason, a better strategy for controlling S. frugiperda by utilizing local natural enemies which are explored from the 
ecosystems in Indonesia, for example, entomopathogenic fungi from soil.

The soil which is a fungal habitat during the saprophytic phase has high entomopathogenic fungi inoculum potential, especially those close to plant roots (Safitri et al. 2018) and is effective in killing the insect pests (Ayudya et al. 2019; Sumikarsih et al. 2019; Gustianingtyas et al. 2020). Research results from other countries show the high pathogenicity of entomopathogenic fungi from soil in controlling $S$. frugiperda population. In Mexico, Beauveria bassiana and Metarhizium anisopliae are reported to be effective in killing $S$. frugiperda larvae (Rivero-Borja et al. 2018) and in Tanzania, the B. bassiana and $M$. anisopliae can suppress the adult population of $S$. frugiperda (Ngangambe and Mwatawala 2020). In India, the $S$. frugiperda were attacked by Nomuraea rileyi (Shylesha et al. 2018). In addition to killing the larvae, the $B$. bassiana and $M$. anisopliae can kill the S. frugiperda eggs (Akutse et al. 2019) and adults (Gutiérrez-Cárdenas et al. 2019). In Cuba, endophytic B. bassiana and $M$. anisopliae were found to be pathogenic to $S$. frugiperda larvae (Ramos et al. 2020). However, the entomopathogenic fungi do not harm the egg and larval parasitoids of $S$. frugiperda (Ngangambe and Mwatawala 2020) and the predatory arthropods (Prabawati et al. 2019). The entomopathogenic fungi can be integrated with botanical insecticides (Hernandez-Trejo et al. 2019) and the entomopathogenic virus, such as nucleopolyhedroviruses (Souza et al. 2019). The entomopathogenic fungi from the South Sumatra soil need to be explored and tested for their pathogenicity against the $S$. frugiperda. The locationspecific fungi are needed because they tend to be more effective than exogenous ones (Thaochan and Sausa-Ard 2017). This study aimed to explore entomopathogenic fungi from soil in South Sumatra and to determine their pathogenicity against $S$. frugiperda larvae.

\section{MATERIALS AND METHODS}

\section{Study area}

The exploration was carried out in soils near the roots of rice, maize, and vegetables following the method Safitri et al. (2018). The explored survey sites were from the lowlands to the highlands of South Sumatra, Indonesia, namely the Districts/Cities of Ogan Komering Ilir, Ogan Ilir, Prabumulih, Muara Enim, Lahat, Pagar Alam, and Banyuasin (Figure 1).

\section{Exploring entomopathogenic fungi}

The collection of entomopathogenic fungi was carried out by modifying the method of Anwar et al. (2015) and Safitri et al. (2018), using a bait method. The bait method used larvae of Tenebrio molitor as insect bait fed in soil samples containing the fungus conidia. The method of soil sampling used the method of Anwar et al. (2015) by digging the soil using a surface soil sampler $(\varnothing 20 \mathrm{~mm})$ as deep as $10-15 \mathrm{~cm}$ around the plant rhizosphere according to the method of Thaochan and Sausa-Ard (2017) and by taking 5 points to collect $1000 \mathrm{~g}$ of soil. Then, the soil sample was put into a plastic bag and labeled with information about the height of the location, type of commodity, soil $\mathrm{pH}$, and date of collection.

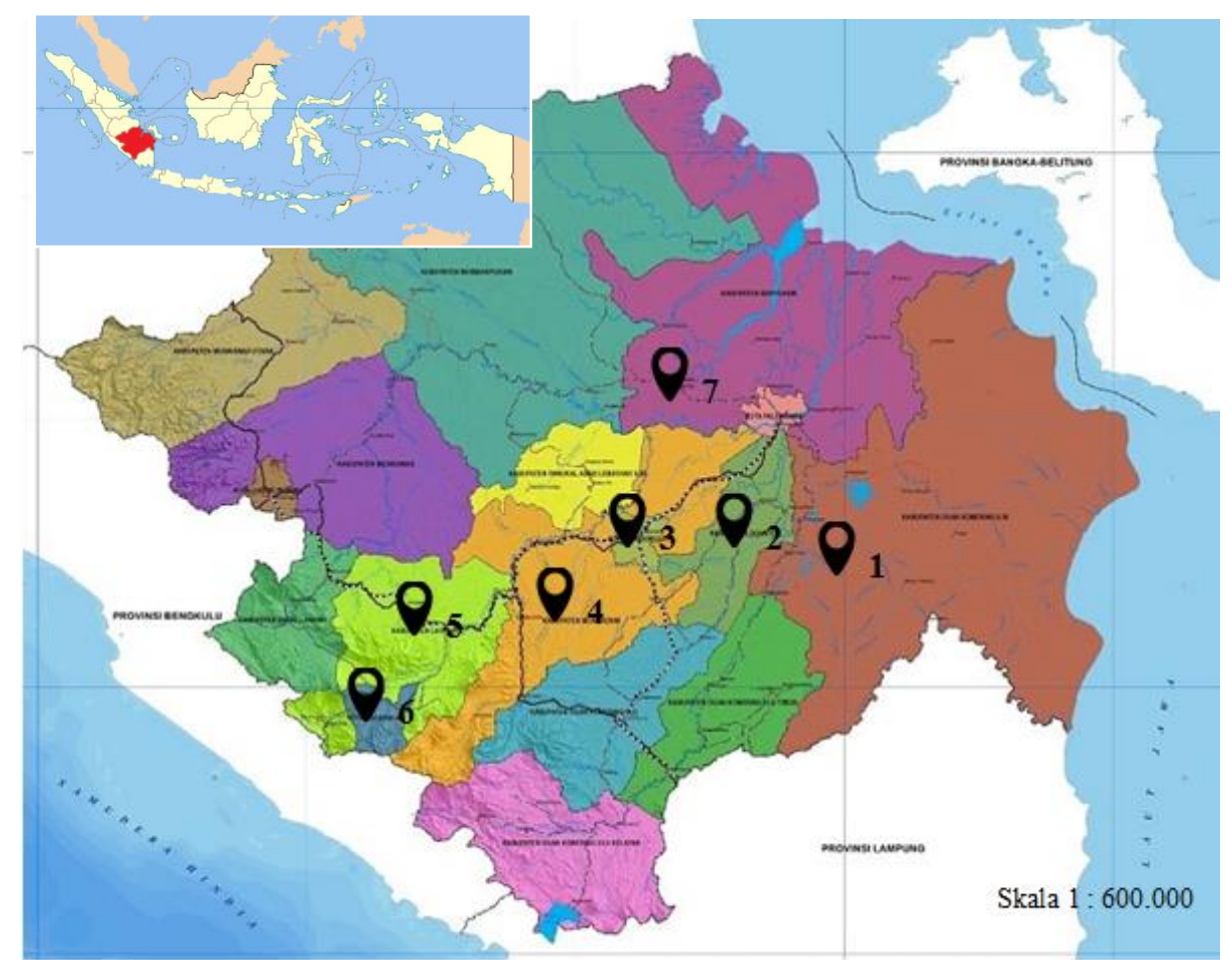

Figure 1. Locations of exploration for entomopathogenic fungi from South Sumatra, Indonesia: 1. Ogan Komering Ilir, 2. Ogan Ilir, 3. Prabumulih, 4. Muara Enim, 5. Lahat, 6. Pagar Alam, and 7. Banyuasin 
The soil sample was first cleaned from plant roots and sieved with 10 mesh sieves. Then, it was put into a plastic tray $\left(32 \times 25 \times 5 \mathrm{~cm}^{3}\right)$ each containing as much as $1000 \mathrm{~g}$. It was then moistened with sterile distilled water with soil moisture exceeding $20 \%$ according to the method of Chen et al. (2014). After that, the 30 newly molted larvae of the third instar T. molitor were placed at the bottom of the tray and the bodies of the larva were sprinkled with a layer of sample soil whose thickness was $20-30 \mathrm{~mm}$. Then the tray containing the sample soil covered with a black cloth and sprayed with sterile aqua dest to maintain soil moisture. The larvae were infested in soil samples for 7 days to allow time for entomopathogenic fungal conidia to infect them, after which the dead larvae infected with entomopathogenic fungi were grown in Sabouraud Dextrose Agar (SDA, Merck) media.

\section{Isolation and identification of the entomopathogenic fungi}

The infected Tenebrio bait was then isolated and purified using the method of Safitri et al. (2018). The entomopathogenic fungi infecting the Tenebrio bait and growing on the surface of the integument were isolated and cultured in the SDA media. The surface of the larvae infected with the entomopathogenic fungi was first sterilized by modifying the method of Sharma et al. (2018) by rinsing with $1 \% \mathrm{NaOCl}$ for 1 minute, then rinsing with $100 \mathrm{~mL}$ of distilled water for 3 times. The surface larvae sterilization was carried out to obtain the fungus that was in the hemocoel or the one that already penetrated the larvae cuticle and prevented the presence of the air fungus. The sterilized larvae were grown in SDA media and incubated for 2 days. Then, the growing fungi were purified in the SDA media to get pure isolates. The entomopathogenic fungi already isolated from $T$. molitor larvae were identified based on the morphological characteristics, for example, the colony colors and shapes of culture on SDA, conidia shape and color using a taxonomic book of Humber (2005) and El-Ghany (2015). The conidia density was calculated using the method of Sumikarsih et al. (2019), while the viability was observed by growing $10 \mu \mathrm{L}$ of fungal conidia suspension $\left(1 \times 10^{6}\right.$ conidia $\left.\mathrm{mL}^{-1}\right)$ on $2 \%$ of agar-water medium, containing $2 \mathrm{~g}$ of agar which was given $100 \mathrm{~mL}$ distilled water (w/v), then the culture was incubated for $2 \times 24$ hours.

\section{Pathogenicity test of the entomopathogenic fungi}

Pathogenicity test has been carried out in Laboratory of Entomology, Department of Plant Pest and Disease, Faculty of Agriculture, Universitas Sriwijaya, Indralaya from January to March 2020. The room temperature and relative humidity during the experiment were $29.30^{\circ} \mathrm{C}$ and $89 \%$. This experiment used the randomized block design with isolates as treatments and was replicated three times.

\section{Preparation of test insect}

$S$. frugiperda larvae were collected from maize fields in Indralaya Village which were not applied with synthetic insecticides. These larvae were brought to the laboratory and kept in plastic cups ( $\varnothing 6.5 \mathrm{~cm}$, height $4.6 \mathrm{~cm})$ porous separately between individuals because of their cannibal nature at room temperature. Into the containers were put the maize leaves to feed $S$. frugiperda and the leaves were replaced daily with fresh new leaves. The last stage larvae entering the pupae stage were transferred into a plastic container $(\varnothing 15 \mathrm{~cm}$, height $25 \mathrm{~cm})$ that was already provided with the soil $(5 \mathrm{~cm}$ thickness $)$ sterilized in the oven for 2 hours at $100^{\circ} \mathrm{C}$. The containers containing pupae were placed in gauze cages $\left(30 \times 30 \times 30 \mathrm{~cm}^{3}\right)$, and the gauze cages were also provided with 10 pieces of water spinach (Ipomoea aquatica) for egg placement for female adults. The water spinach was placed in a plastic bottle $(\varnothing$ $5.5 \mathrm{~cm}$, height $17 \mathrm{~cm}$ ) containing tap water height of $10 \mathrm{~cm}$ to maintain its freshness. The egg clutch placed by the adults on the surface of the water spinach leaves were moved into the container containing the water spinach leaves. The feed for the first instar larvae was water spinach leaves. After molting the skin, the second-instar larvae until the last instar were fed young maize leaves. The larvae of the second instar to the last one were kept separately in a porous plastic cup $(\varnothing 6.5 \mathrm{~cm}$, height $4.6 \mathrm{~cm})$ because the second instar and so on were cannibalistic. Mass-rearing was carried out to obtain the third generation of culture. The second stage larvae aged 1 day were used for test insects in this study.

\section{Fungus application}

The suspension of each isolate culture of the fungus aged $7 \times 24$ hours with a concentration of $1 \times 10^{6}$ conidia $\mathrm{mL}^{-1}$ of $1 \mathrm{~mL}$ was dripped on maize leaves and topically also applied to the larvae, then the maize leaf was forced to be eaten by the second instar larvae of $S$. frugiperda as much as 25 larvae per isolate for 6 hours and it was repeated three times. The larvae before being treated were first fasted for 2 hours and weighed using a Portable Jewelry Scale (capacity of $30 \mathrm{~g} \mathrm{x} 0.01 \mathrm{~g}$ ). After 6 hours of infestation and confirmed that all larvae already ate the leaves moistened with the fungus suspension, then they were transferred into a porous plastic cup $(\varnothing 6.5 \mathrm{~cm}$, height $4.6 \mathrm{~cm}$ ) and each cup contained only 1 larvae and provided $2 \times 5 \mathrm{~cm}^{2}$ maize leaves per day per larvae. To measure the percentage of leaf area eaten (foliar damage caused) by the larvae of $S$. frugiperda used bioleaf application by Machado et al. (2016). Every 1 x 24 hours the dead test larvae were recorded and it was carried out for 12 days based on the previous research by Ayudya et al. (2019) and the number of larvae becoming pupae and the pupae becoming adults were also counted. The number of dead larvae was used to calculate mortality, the Median Lethal Time $\left(\mathrm{LT}_{50}\right)$, and the $90 \%$ of Lethal Time $\left(\mathrm{LT}_{95}\right)$. The area of the eaten maize leaves, the weight of the feces, and the weight of the larvae body were measured every day from the first day to the 12th.

\section{Data analysis}

The data differences among the larval weight data, eaten leaf area, and feces produced each day among the isolate treatments, and mortality and time of death (the $\mathrm{LT}_{50}$ and $\mathrm{LT}_{95}$ ) larvae of $S$. frugiperda, the percentage of larvae into pupae and pupae into adults were analyzed using analysis of variance (ANOVA). The Tukey's 
Honestly Significant Difference (HSD) test was employed to test the significant differences among the treatments (isolates) at $\mathrm{P}=0.05$. The $\mathrm{LT}_{50}$ and $\mathrm{LT}_{95}$ values were calculated by using probit analysis. All data were calculated using SAS University Edition software 2.7 9.4 M5.

\section{RESULTS AND DISCUSSION}

\section{The entomopathogenic fungi found in the survey}

The entomopathogenic fungi that were found could only be identified up to Genus. All isolates (14 isolates) found belong to one genus, all Metarhizium (Table 1). These isolates were found from 14 locations spreading from the lowlands to the highlands of South Sumatra. The isolates of entomopathogenic fungi were isolated from the soil near the roots of rice, maize, and vegetables depending on the presence of the plants during the survey. The soil $\mathrm{pH}$ of the survey site varied between 5 and 6.8 and the low $\mathrm{pH}$ was generally found in the lowlands, while in the highlands the soil $\mathrm{pH}$ was relatively higher.

Macroscopically, all isolates of Metarhizium sp. growing on SDA media had a colony that was initially clear, then developed to a yellowish-white color, then white hyphae formed mycelia and continued to grow and spread evenly, the older they were (5-7 days) the more evenly they spread and produced dark green conidia shaped like flour (powdery) (Figure 2). Microscopically, conidia Metarhizium sp. was cylindrical, single, one-celled, hyaline, and its length ranged from 8 to $10 \mu \mathrm{m}$, while the mycelium was insulated.

Conidia density of 14 isolates of Metarhizium sp. found in this study did not show significant differences among the isolates (Table 2). The viability of conidia both incubated 1 x 24 hours and 2 x 24 hours also did not show significant differences among the isolates. The viability of conidia increased after being incubated for $2 \times 24$ hours.

\section{Fungal pathogenicity against the Spodoptera frugiperda larvae}

The measurement of leaf area eaten by the treated larvae with entomopathogenic fungi $1 \times 10^{6}$ conidia $\mathrm{mL}^{-1}$ from the first to the fourth day showed that the consumed leaf area was not significantly different from those eaten by the untreated (control) larvae. However, starting on the fifth day, the treated $S$. frugiperda larvae began to significantly decrease its appetite when compared to the untreated larvae (Table 3). On the following day, the leaf area eaten by the treated larvae with the fungus remained lower than that of the control. The symptoms of the leaves eaten by the treated and untreated larvae also showed differences (Figure 3). The decreased appetite in the treated larvae with the fungus did not show consistency in the larvae weight loss, yet on the third day of the observation, the treated larvae body weight was significantly lower than that of the untreated larvae weight (Table 4). From the 4th to the 6th days of the observations, all treatments of the larvae body weight showed no significant difference, but on the seventh, to the twelfth days, there was one isolate (PdmOI) which consistently reduced the weight of $S$. frugiperda larvae. The weight of feces produced by the treated and control larvae tended to show a significant difference, i.e. the feces weight produced by the treated larvae tended to be lighter than that of the untreated (control) larvae (Table 5).

All Metahrizium isolates tested against the $S$. frugiperda larvae were pathogenic (70.67-78.67\%); the most pathogenic caused $78.67 \%$ of the mortality and significantly suppressed the emergence of adults up to $81.2 \%$ (Table 6 and Figure 4) and they were significantly higher than the untreated larvae (control) (13.33\%). Although the mortality among the isolates did not show any significant difference, $\mathrm{LT}_{50}$ (6.43 days) and $\mathrm{LT}_{95}$ (12.57 days) were found most briefly in PirOI isolates originating from the soil near the rice roots in the lowlands of Pemulutan Ilir, Ogan Ilir District (Table 6). The treated larvae that were still alive and turned into pupae were only around $21.3-29.3 \%$ and the larvae that successfully became into adults were only around $18.8-28 \%$, while the untreated larvae managed to become adults as many as $86.67 \%$ (Table 7). The lowest emergence of adults (18.8\%) was found in CasPsPGA isolates originating from the soil near the roots of chili in the highlands of Pasai, Kota Pagar Alam with $\mathrm{LT}_{50}$ for only 6.68 days. Consequently, the fungi in this study could reduce the emergence of $S$. frugiperda adults up to $81.2 \%$.

Table 1. Species and isolates of entomopathogenic fungi found from soil in South Sumatra, Indonesia

\begin{tabular}{llllccc}
\hline \multicolumn{1}{c}{ District/City } & \multicolumn{1}{c}{ Village } & \multicolumn{1}{c}{ Crop plants } & Species of fungi & Isolate codes & Soil pH & Altitude (m) \\
\hline Muara Enim & Talang Taling & Pumpkin & Metarhizium sp. & LpTtME & 5.5 & 67.2 \\
Ogan Ilir & Pemulutan Ilir & Paddy & Metarhizium sp. & PirOI & 5.2 & 11.5 \\
Pagar Alam & Pasai & Eggplant & Metarhizium sp. & TePsPGA & 6.0 & 870.0 \\
Ogan Ilir & Bakung & Tomato and maize & Metarhizium sp. & ToBkOI & 6.0 & 11.5 \\
Prabumulih & Gunung Ibul & Chili & Metarhizium sp. & CaGiPR & 5.6 & 64.3 \\
Prabumulih & Sindur & Chili & Metarhizium sp. & CaSnPR & 5.7 & 27.6 \\
Muara Enim & Talang Taling & Chili & Metarhizium sp. & CaTtME & 5.5 & 67.2 \\
Ogan Komering Ilir & Lempuing & Cucumber & Metarhizium sp. & TiCmLpOKI & 5.6 & 19 \\
Ogan Ilir & Bakung & Chili and maize & Metarhizium sp. & CaBkOI & 6.0 & 11.5 \\
Pagar Alam & Pasai & Chili & Metarhizium sp. & CasPsPGA & 5.9 & 870.0 \\
Ogan Ilir & Semambu Seteko & Bitter melon & Metarhizium sp. & PrSestOI & 5.6 & 22.7 \\
Muara Enim & Skarda & Eggplant & Metarhizium sp. & TeSkME & 5.1 & 60.7 \\
Ogan Ilir & Pelabuhan Dalam & Paddy & Metarhizium sp. & PdmOI & 5.0 & 15.8 \\
Lahat & Merapi Timur & Peanuts & Metarhizium sp. & KtMtLH & 6.8 & 112.0 \\
\hline
\end{tabular}




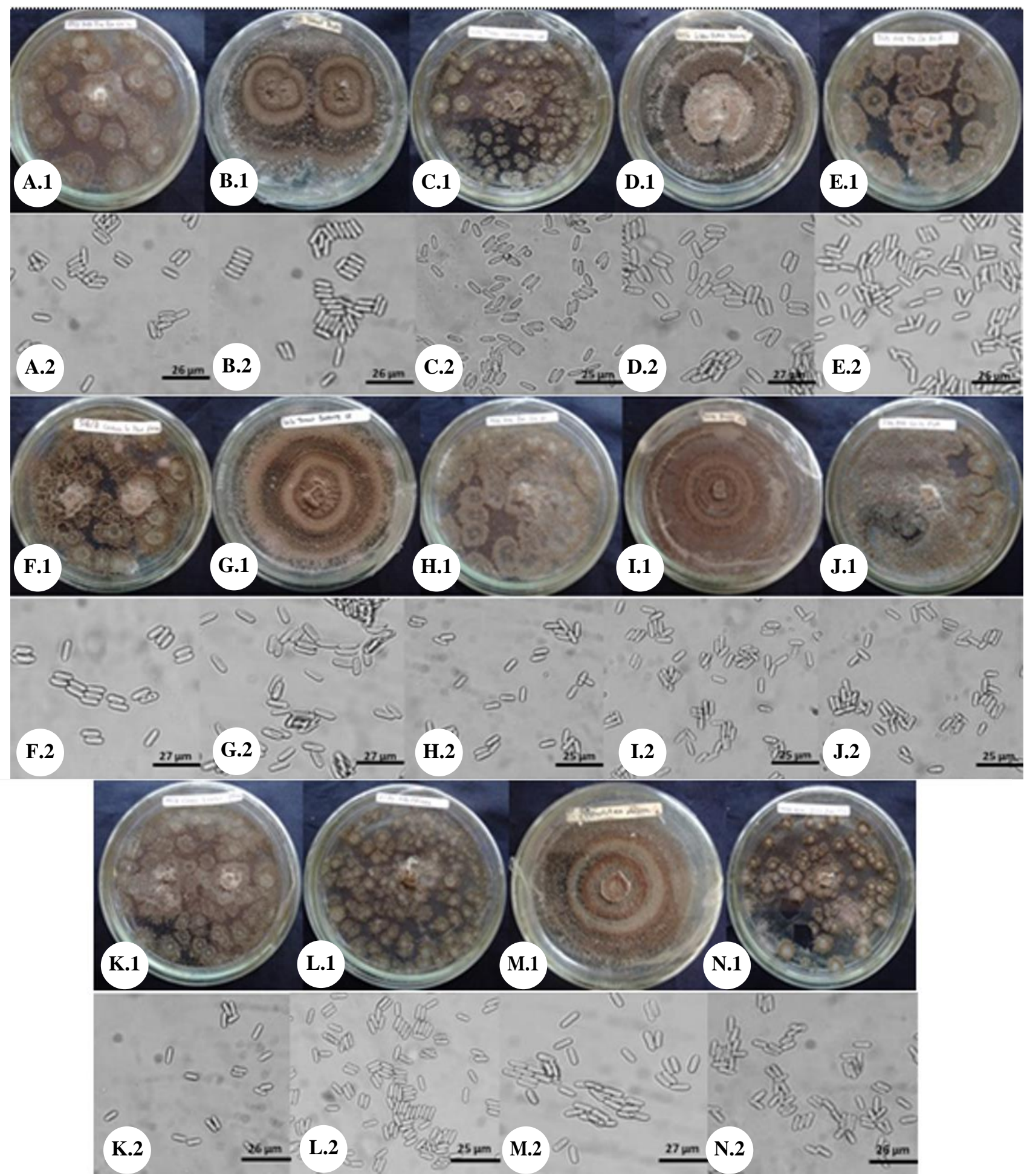

Figure 2. Colonial (above) and conidial (below) morphology of Metarhizium spp. on culture SDA: CaBkOI (A), CaTtME (B), TiCmLpOKI (C), LpTtME (D), TeSkME (E), CaGiPR (F), ToBkOI (G), PrSeStOI (H), TePsPGA (I), CasPsPGA (J), CaSnPR (K), PirOI (L), PdmOI (M), dan KtMtLH (N)

The treated dead larvae showed typical symptoms that distinguished them from healthy larvae. The treated larvae's body was dry, contracted, shrinking, odorless, and the integument was covered by mycelia and conidia like yellowish-white flour mixed with dark green (Figure 5). The treated larvae could produce abnormal and malformation pupae, while the untreated larvae could produce healthy normal pupae (Figure 6). The abnormal pupae were shorter in size, bent, wrinkled wings to-be, darker color, not moving when touched with a brush, and unable to become adults. The adults formed from the treated larvae had folded wings and were smaller than the 
untreated larvae (Figure 7). However, this study did not measure the length of pupae and adults formed but only documented in the form of photographs. From the data, the entomopathogenic fungi could kill $S$. frugiperda larvae and pupae, produce abnormal pupae and adults, and reduce the percentage of their adult emergence.

The entomopathogenic fungi can be found from the lowlands to the highlands of South Sumatra because the source of the fungus inoculum in the soil near the roots in this study has a $\mathrm{pH}$ range of 5-6.8. The Soil $\mathrm{pH}$ determines the presence of the fungus inoculums; the fungi can survive as saprophytes in soil whose $\mathrm{pH}$ ranges from 4 to 6.7 (Safitri et al. 2018). In the low acidity and moisture, soil is more easily found fungi in the saprophytic phase (Thaochan and Sausa-Ard 2017). On in vitro media, the entomopathogenic fungi can still grow at a $\mathrm{pH}$ ranging from 3 to 9 , while the ideal $\mathrm{pH}$ for fungal growth ranges from 6 to 7 (Karthikeyan et al. 2008). In addition to $\mathrm{pH}$ soil moisture content also influences the presence of entomopathogenic fungi, and in soil moisture 6-21\%, Beauveria bassiana conidia are still found to be pathogenic and capable of killing up to $80 \%$ of Anastrepha ludens adults (Wilson et al. 2020). The ideal in vitro medium moisture for the entomopathogenic fungi to survive ranges from $15 \%$ to $35 \%$ and the optimum moisture is $35 \%$ (Chen et al. 2014). In this study, the soil moisture in the survey location ranged from $13 \%$ to $20.9 \%$ which is the range of moisture suitable for saprophytic fungal habitat.

The fungi found in this study have morphological characteristics in accordance with the characteristics of the Genus, Metarhizium which has been described by Thaochan and Sausa-Ard (2017), Lopes et al. (2018), and Chen et al. (2019). The fungus colony form in the agar medium is initially colorless, then becomes light yellow after the colony is more than 5 days old, the conidia turns green which indicates that the conidia are matured with the conidial mass bluish olive (Thaochan and Sausa-Ard 2017; Lopes et al. 2018) The color of conidia of Metarhizium varies from yellow to green (Chen et al. 2019). The Metarhizium has cylindrical, single and one-celled, and hyaline conidia, while the hyphae septate, smooth-walled, and hyaline (Lopes et al. 2018; Chen et al. 2019), the length of the Metarhizium conidia ranges from 7.3 to 14.4 $\mu \mathrm{m}$ (Chen et al. 2019) and this measure of the fungal conidia in this study $(8-10 \mu \mathrm{m})$ falls into the above range.

Table 2. Mean of conidial density and viability of entomopathogenic fungal isolates

\begin{tabular}{lccc}
\hline \multirow{2}{*}{ Isolates } & $\begin{array}{c}\text { Conidial density } \\
\mathbf{1 x 1 0}^{8}\end{array}$ & \multicolumn{2}{c}{ Conidial viability (\%) } \\
\cline { 3 - 4 }${\text { (conidia } \mathbf{~ m L}^{-1} \text { ) }}^{\mathbf{2 4}}$ & $\begin{array}{c}\mathbf{2 4} \text {-hour } \\
\text { culture }\end{array}$ & $\begin{array}{c}\mathbf{4 8} \text {-hour } \\
\text { culture }\end{array}$ \\
\hline LpTtME & $5.11 \pm 0.80$ & $58.33 \pm 5.42$ & $68.00 \pm 2.49$ \\
PirOI & $4.63 \pm 0.11$ & $53.33 \pm 1.52$ & $62.67 \pm 4.91$ \\
TePsPGA & $3.69 \pm 0.28$ & $53.67 \pm 4.25$ & $62.67 \pm 7.09$ \\
ToBkOI & $5.13 \pm 0.10$ & $58.67 \pm 6.28$ & $67.33 \pm 5.66$ \\
CaGiPR & $4.24 \pm 0.08$ & $49.67 \pm 4.06$ & $59.67 \pm 3.34$ \\
CaSnPR & $4.60 \pm 0.59$ & $51.33 \pm 3.54$ & $57.67 \pm 2.88$ \\
CaTtME & $5.69 \pm 0.83$ & $50.33 \pm 3.31$ & $65.67 \pm 5.04$ \\
TiCmLpOKI & $5.06 \pm 0.14$ & $56.33 \pm 1.78$ & $61.33 \pm 4.84$ \\
CaBkOI & $4.52 \pm 0.59$ & $59.33 \pm 1.91$ & $61.33 \pm 5.19$ \\
CasPsPGA & $5.16 \pm 0.25$ & $67.00 \pm 2.05$ & $62.33 \pm 6.28$ \\
PrSeStOI & $5.08 \pm 0.27$ & $56.67 \pm 3.93$ & $63.00 \pm 4.78$ \\
TeSkME & $4.68 \pm 0.22$ & $57.67 \pm 4.23$ & $64.67 \pm 5.86$ \\
PdmOI & $5.29 \pm 0.32$ & $53.67 \pm 5.19$ & $68.67 \pm 4.38$ \\
KtMtLH & $4.79 \pm 0.11$ & $48.67 \pm 4.23$ & $69.33 \pm 3.03$ \\
F-value & $1.37^{\text {ns }}$ & $1.01^{\text {ns }}$ & $0.35^{\text {ns }}$ \\
P value & 0.23 & 0.47 & 0.98
\end{tabular}

HSD value

Note: $n s=$ not significantly different; values within a column (the data of each isolate) followed by the same letters were not significantly different at $\mathrm{P}<0.05$ according to Tukey's HSD test.

Table 3. Mean of leaf area eaten by Spodoptera frugiperda larvae treated with entomopathogenic fungal isolates with $1 \times 10^{6}$ conidia $\mathrm{mL}^{-1}$

\begin{tabular}{|c|c|c|c|c|c|c|c|c|c|c|c|c|}
\hline \multirow{2}{*}{ Isolates } & \multicolumn{12}{|c|}{ Leaf area eaten by larvae $\left(\mathrm{cm}^{2}\right.$ larvae $^{-1}$ day $\left.^{-1}\right)$ on observation for 12 days } \\
\hline & 1 & 2 & 3 & 4 & 5 & 6 & 7 & 8 & 9 & 10 & 11 & 12 \\
\hline Control & 3.91 & 4.02 & 8.96 & 8.64 & $9.67 \mathrm{~b}$ & $8.85 \mathrm{~b}$ & $9.09 \mathrm{~b}$ & $9.37 \mathrm{~b}$ & $9.41 \mathrm{~b}$ & $9.46 \mathrm{~b}$ & $9.46 \mathrm{~b}$ & $9.28 \mathrm{~b}$ \\
\hline LpTtME & 3.89 & 4.17 & 8.01 & 9.44 & $8.82 \mathrm{ab}$ & $7.48 \mathrm{ab}$ & $7.04 \mathrm{a}$ & $7.00 \mathrm{a}$ & $7.06 \mathrm{a}$ & $7.11 \mathrm{ab}$ & $7.35 \mathrm{a}$ & $6.24 \mathrm{a}$ \\
\hline PirOI & 3.98 & 3.94 & 7.98 & 10.43 & $8.26 \mathrm{ab}$ & $6.80 \mathrm{a}$ & $6.81 \mathrm{a}$ & & & & $7.23 \mathrm{a}$ & $6.03 \mathrm{a}$ \\
\hline TePsPGA & 4.03 & 4.02 & 7.54 & 8.83 & $7.53 \mathrm{a}$ & $6.81 \mathrm{a}$ & $7.45 \mathrm{ab}$ & $6.87 \mathrm{a}$ & $6.95 \mathrm{a}$ & $6.67 \mathrm{a}$ & $7.10 \mathrm{a}$ & $6.12 \mathrm{a}$ \\
\hline ToBkOI & 3.91 & 3.88 & 7.64 & 10.08 & $8.25 \mathrm{ab}$ & $7.22 \mathrm{a}$ & $6.86 \mathrm{a}$ & $7.11 \mathrm{a}$ & $7.38 \mathrm{a}$ & $6.41 \mathrm{a}$ & $7.02 \mathrm{a}$ & $5.80 \mathrm{a}$ \\
\hline CaGiPR & 4.13 & 4.07 & 7.73 & 9.88 & $7.75 \mathrm{a}$ & $7.06 \mathrm{a}$ & $7.02 \mathrm{a}$ & $7.01 \mathrm{a}$ & $6.95 \mathrm{a}$ & $6.97 \mathrm{a}$ & $7.29 \mathrm{a}$ & $7.16 \mathrm{a}$ \\
\hline CaSnPR & 4.08 & 4.14 & 7.78 & 9.99 & $8.06 \mathrm{ab}$ & $6.89 \mathrm{a}$ & $7.30 \mathrm{ab}$ & $6.71 \mathrm{a}$ & $6.59 \mathrm{a}$ & $7.14 \mathrm{a}$ & $7.76 \mathrm{a}$ & $6.54 \mathrm{a}$ \\
\hline CaTtME & 4.00 & 4.01 & 8.15 & 9.11 & $8.07 \mathrm{ab}$ & $7.11 \mathrm{a}$ & $6.73 \mathrm{a}$ & $7.07 \mathrm{a}$ & $6.90 \mathrm{a}$ & $6.86 \mathrm{a}$ & $7.21 \mathrm{a}$ & $7.13 \mathrm{a}$ \\
\hline TiCmLpOKI & 4.09 & 4.23 & 8.06 & 9.50 & $8.21 \mathrm{ab}$ & $6.66 \mathrm{a}$ & $7.99 \mathrm{ab}$ & $6.89 \mathrm{a}$ & $7.57 \mathrm{a}$ & $7.27 \mathrm{a}$ & $6.67 \mathrm{a}$ & $7.17 \mathrm{a}$ \\
\hline $\mathrm{CaBkOI}$ & 4.07 & 4.16 & 8.13 & 10.28 & $8.01 \mathrm{ab}$ & $7.28 \mathrm{a}$ & $7.20 \mathrm{ab}$ & $6.89 \mathrm{a}$ & $6.90 \mathrm{a}$ & $6.70 \mathrm{a}$ & $6.96 \mathrm{a}$ & $6.68 \mathrm{a}$ \\
\hline CasPsPGA & 4.03 & 4.05 & 7.68 & 9.73 & $7.56 \mathrm{a}$ & $6.76 \mathrm{a}$ & $6.41 \mathrm{a}$ & $6.92 \mathrm{a}$ & $7.38 \mathrm{a}$ & $7.78 \mathrm{a}$ & $7.16 \mathrm{a}$ & $7.00 \mathrm{a}$ \\
\hline PrSeStOI & 4.12 & 4.07 & 8.17 & 9.77 & $8.11 \mathrm{ab}$ & $6.85 \mathrm{a}$ & $7.43 \mathrm{ab}$ & $7.05 \mathrm{a}$ & $6.96 \mathrm{a}$ & $7.25 \mathrm{a}$ & $7.40 \mathrm{a}$ & $6.62 \mathrm{a}$ \\
\hline TeSkME & 4.12 & 3.96 & 8.01 & 10.27 & $7.94 \mathrm{a}$ & $7.00 \mathrm{a}$ & $6.94 \mathrm{a}$ & $7.34 \mathrm{a}$ & $6.97 \mathrm{a}$ & $7.08 \mathrm{a}$ & $7.07 \mathrm{a}$ & $6.45 \mathrm{a}$ \\
\hline PdmOI & 4.09 & 4.05 & 8.38 & 10.07 & $7.46 \mathrm{a}$ & $7.31 \mathrm{a}$ & $6.33 \mathrm{a}$ & $6.93 \mathrm{a}$ & $7.29 \mathrm{a}$ & $7.31 \mathrm{a}$ & $7.07 \mathrm{a}$ & $6.92 \mathrm{a}$ \\
\hline KtMtLH & 4.04 & 3.98 & 8.17 & 9.33 & $7.69 \mathrm{a}$ & $6.54 \mathrm{a}$ & $6.50 \mathrm{a}$ & $7.02 \mathrm{a}$ & $6.59 \mathrm{a}$ & $6.97 \mathrm{a}$ & $7.44 \mathrm{a}$ & $6.91 \mathrm{a}$ \\
\hline F-value & $1.07^{\mathrm{ns}}$ & $0.36^{\mathrm{ns}}$ & $1.02^{\mathrm{ns}}$ & $1.90^{\mathrm{ns}}$ & $2.81^{*}$ & $3.24 *$ & $3.32 *$ & $2.70 *$ & $4.78^{*}$ & $6.18 *$ & $3.34 *$ & $5.73 *$ \\
\hline$P$ value & 0.42 & 0.98 & 0.46 & 0.07 & 0.01 & 0.00 & 0.00 & 0.01 & 0.00 & 0.00 & 0.00 & 0.00 \\
\hline HSD value & - & - & - & - & 1.72 & 1.57 & 1.96 & 2.02 & 1.60 & 1.48 & 1.79 & 1.74 \\
\hline
\end{tabular}

Note: $\mathrm{ns}=$ not significantly different; $*$ = significantly different; values within a column (the data of each isolate) followed by the same letters were not significantly different at $\mathrm{P}<0.05$ according to Tukey's HSD test 
Table 4. Mean of weight of Spodoptera frugiperda larvae treated with entomopathogenic fungal isolates with $1 \times 10^{6} \mathrm{conidia}_{\mathrm{mL}}^{-1}$

\begin{tabular}{|c|c|c|c|c|c|c|c|c|c|c|c|c|}
\hline \multirow[t]{2}{*}{ Isolates } & \multicolumn{12}{|c|}{ Larval weight $\left(\mathrm{mg} \mathrm{larvae}^{-1}\right)$ on observation for 12 days } \\
\hline & 1 & 3 & 3 & 4 & 5 & 6 & 7 & 8 & 9 & 10 & 11 & 12 \\
\hline Control & $3.90 \mathrm{~b}$ & 6.93 & $17.93 \mathrm{~b}$ & 23.68 & 26.85 & 36.72 & $42.94 \mathrm{ab}$ & $52.99 \mathrm{ab}$ & $64.40 \mathrm{ab}$ & $81.33 \mathrm{abc}$ & $88.10 \mathrm{ab}$ & $112.73 \mathrm{ab}$ \\
\hline LpTtME & $3.51 \mathrm{a}$ & 5.68 & $11.23 \mathrm{a}$ & 17.34 & 24.14 & 38.53 & $49.08 \mathrm{ab}$ & $56.94 \mathrm{ab}$ & $74.63 \mathrm{ab}$ & $84.17 \mathrm{abc}$ & $98.83 \mathrm{ab}$ & $0.38 \mathrm{ab}$ \\
\hline PirOI & $3.47 \mathrm{a}$ & 6.14 & $10.92 \mathrm{a}$ & 21.35 & 27.84 & 41.72 & $54.95 \mathrm{~b}$ & $71.65 \mathrm{~b}$ & $95.01 \mathrm{~b}$ & $117.68 \mathrm{c}$ & $132.59 \mathrm{~b}$ & $159.13 \mathrm{~b}$ \\
\hline TePsPGA & $3.80 \mathrm{a}$ & 5.93 & $10.00 \mathrm{a}$ & 17.84 & 28.69 & 36.41 & $51.26 \mathrm{ab}$ & $61.08 \mathrm{ab}$ & $74.54 \mathrm{ab}$ & $90.64 \mathrm{abc}$ & $102.06 \mathrm{ab}$ & $117.57 \mathrm{ab}$ \\
\hline ToBkOI & $2.49 \mathrm{a}$ & 5.04 & $9.35 \mathrm{a}$ & 18.16 & 26.40 & 35.81 & $46.20 \mathrm{ab}$ & & $67.81 \mathrm{ab}$ & $91.95 \mathrm{abc}$ & $103.89 \mathrm{ab}$ & $120.03 \mathrm{ab}$ \\
\hline CaGiPR & $2.29 \mathrm{a}$ & 6.02 & $11.36 \mathrm{a}$ & 17.22 & 25.00 & 32.79 & $47.19 \mathrm{ab}$ & & $72.42 \mathrm{ab}$ & $86.91 \mathrm{abc}$ & & $149.44 \mathrm{ab}$ \\
\hline CaSnPR & $33 \mathrm{a}$ & 5.89 & $10.47 \mathrm{a}$ & 20.48 & 27.30 & 36.76 & $50.67 \mathrm{ab}$ & & $80.36 \mathrm{ab}$ & & & $138.70 \mathrm{ab}$ \\
\hline CaTtM & $69 \mathrm{a}$ & 8.23 & $11.50 \mathrm{a}$ & 17.91 & 23.22 & 32.69 & $46.86 \mathrm{ab}$ & & $76.13 \mathrm{ab}$ & & 105.2 & $125.29 \mathrm{ab}$ \\
\hline TiCmLpOKI & $1.77 \mathrm{a}$ & 5.29 & $12.61 \mathrm{a}$ & 9.41 & 26.09 & 34.93 & & & $61.31 \mathrm{ab}$ & & & $97.44 \mathrm{ab}$ \\
\hline CaBkOI & $3.09 \mathrm{a}$ & 6.30 & $12.49 \mathrm{a}$ & 3.14 & 25.09 & 33. & $45.94 \mathrm{ab}$ & & $77.05 \mathrm{ab}$ & & 104.8 & $.39 a b$ \\
\hline & & 6.08 & & & 26. & & & & $85.10 \mathrm{ab}$ & & $122.99 \mathrm{ab}$ & \\
\hline & $3.96 \mathrm{~b}$ & 6.07 & & & 23.75 & & & & $76.11 \mathrm{ab}$ & $83.97 \mathrm{abc}$ & $97.10 \mathrm{ab}$ & 120.6 \\
\hline & $04 \mathrm{a}$ & 7.07 & & & 25.34 & & $40.15 a b$ & $a b$ & $64.13 \mathrm{ab}$ & 73.6 & 91.4 & $101.15 \mathrm{ab}$ \\
\hline & & 4.86 & & & 22.23 & & $35.64 \mathrm{a}$ & & & & & $94.76 \mathrm{a}$ \\
\hline & 59 a & 6.99 & & & 27.86 & & & & $9 a b$ & $107.28 \mathrm{bc}$ & 118.5 & $142.51 \mathrm{ab}$ \\
\hline & $7.54 *$ & $1.41^{\mathrm{ns}}$ & & & $0.78^{\mathrm{ns}}$ & 1.5 & & & & & & $2.27 *$ \\
\hline & & 0.21 & & 0.08 & 0.68 & 0.15 & & & & & & 0.03 \\
\hline HSD value & 2.73 & - & 4.94 & - & - & - & 16.16 & 23.96 & 35.98 & 40.82 & 48.91 & 63.10 \\
\hline
\end{tabular}

Note: ns: not significantly different; *: significantly different; values within a column (the data of each isolate) followed by the same letter were not significantly different at $\mathrm{P}<0.05$ according to Tukey's HSD test

Table 5. Mean of feces weight produced by Spodoptera frugiperda larvae treated with entomopathogenic fungal isolates with $1 \times 10^{6}$ conidia $\mathrm{mL}^{-1}$

\begin{tabular}{|c|c|c|c|c|c|c|c|c|c|c|c|c|}
\hline \multirow[t]{2}{*}{ Isolates } & \multicolumn{12}{|c|}{ Larval feces weight (mg larvae ${ }^{-1}$ day $\left.^{-1}\right)$ on observation for 12 days } \\
\hline & 1 & 3 & 3 & 4 & 5 & 6 & 7 & 8 & 9 & 10 & 11 & 12 \\
\hline Control & 1.97 & 5.05 & $7.23 \mathrm{~b}$ & $11.15 \mathrm{~b}$ & $16.14 \mathrm{c}$ & $20.56 \mathrm{~d}$ & $23.50 \mathrm{c}$ & $27.23 \mathrm{c}$ & $28.32 \mathrm{c}$ & $30.60 \mathrm{~b}$ & $4.39 \mathrm{~b}$ & $36.40 \mathrm{~b}$ \\
\hline LpTtM & 1.78 & 3.63 & $70 \mathrm{~b}$ & & & $59 \mathrm{ab}$ & $.18 \mathrm{ab}$ & & $37 \mathrm{ab}$ & $.38 \mathrm{a}$ & $5.52 \mathrm{a}$ & $17.18 \mathrm{a}$ \\
\hline PirOI & 1.59 & 2.71 & $6.08 \mathrm{ab}$ & $7.41 \mathrm{ab}$ & $9.59 \mathrm{ab}$ & $9.37 \mathrm{abc}$ & $11.92 \mathrm{ab}$ & & & $.57 \mathrm{a}$ & $24.70 \mathrm{ab}$ & $22.07 \mathrm{a}$ \\
\hline TePsPGA & 1.02 & 2.38 & $4.80 \mathrm{ab}$ & $7.07 \mathrm{ab}$ & $6.49 \mathrm{ab}$ & & & & & $6.21 \mathrm{a}$ & $16.76 \mathrm{a}$ & $17.50 \mathrm{a}$ \\
\hline & & 2.40 & $5.28 \mathrm{ab}$ & & $5.67 \mathrm{a}$ & & & & & & $9.41 \mathrm{a}$ & $20.61 \mathrm{a}$ \\
\hline & & 2.65 & & $8.01 \mathrm{ab}$ & $5.77 \mathrm{ab}$ & & & $3 a b$ & & & $20.07 \mathrm{a}$ & $22.96 \mathrm{a}$ \\
\hline & & 2.67 & $7.07 \mathrm{~b}$ & & $9.50 \mathrm{ab}$ & & 13.07 & & & & $21.31 \mathrm{a}$ & $23.49 \mathrm{ab}$ \\
\hline CaTtI & & 3.44 & $4.11 \mathrm{ab}$ & & $8.62 \mathrm{ab}$ & & 11.95 & & & $87 \mathrm{ab}$ & $22.17 \mathrm{a}$ & $21.52 \mathrm{a}$ \\
\hline & 0.99 & 3.04 & & 8.6 & $10.23 \mathrm{abc}$ & & 11.2 & $a b c$ & & & & $17.31 \mathrm{a}$ \\
\hline $\mathrm{CaBk}$ & & 3.27 & & & $9.78 \mathrm{ab}$ & & & & & $1 \mathrm{ab}$ & $9 \mathrm{a}$ & $89 a$ \\
\hline & & 2.74 & & & $10.83 a b c$ & & & & & $77 \mathrm{ab}$ & $90 \mathrm{a}$ & $21.62 \mathrm{a}$ \\
\hline & & 3.14 & & & & & 15.0 & & & $28 \mathrm{a}$ & $59 a$ & $23.01 \mathrm{a}$ \\
\hline & & 2.72 & & & & & & & & & $58 \mathrm{a}$ & $18.80 \mathrm{a}$ \\
\hline & & 3.07 & & & & 9.4 & & & & & $9 \mathrm{a}$ & $77 \mathrm{a}$ \\
\hline & & 2.75 & & 7.3 & & & 12. & & $a b c$ & & $22.29 \mathrm{a}$ & $4 a b$ \\
\hline & $24^{\mathrm{ns}}$ & $2.01^{\mathrm{ns}}$ & & & & & & & & & $4.34 *$ & $3.57 *$ \\
\hline & & 0.05 & & & & & & & & & & \\
\hline HSD value & - & - & 4.40 & 4.24 & 6.13 & 4.70 & 7.33 & 10.10 & 12.53 & 11.38 & 11.82 & 13.14 \\
\hline
\end{tabular}

Note: ns: not significantly different; *: significantly different; values within a column (the data of each isolate) followed by the same letter were not significantly different at $\mathrm{P}<0.05$ according to Tukey's HSD test

In this study, the two most pathogenic isolates of $S$. frugiperda larvae and pupae characterized by the highest mortality of larvae and pupae and able to kill them in the shortest amount of time were PirOI and CasPsPGA isolates. The PirOI isolates originate from the soil near rice roots in the lowlands, while CasPsPGA isolates originate from the soil near chilli roots in the highlands. The soil origin of the isolate did not determine the virulence of the fungus, in line with the results of the study (Thaochan and Sausa-Ard 2017) stating that the original host or the geographic origin of the isolate has no association with the virulence of the fungus. The virulence of this fungus is more determined by the ability of germ tubes of conidia to penetrate the insect cuticle when it infects its host insect (El-Ghany 2015). The discovery of the two most pathogenic isolates originating from the lowlands and highlands of South Sumatra is a useful finding to develop local-specific mycoinsecticides to control pest insects in the highlands and/or lowlands. Because $S$. frugiperda is a maize insect pest spreading from the lowlands to highlands in South Sumatra in particular and Indonesia in general, the location-specific entomopathogenic fungi are needed. 
The data of area of the leaves eaten by the treated larvae showed the entomopathogenic fungus, Metarhizium sp. can reduce larvae appetite and reduce larvae weight. On the fifth day of observation, the treated S. frugiperda larvae began to significantly decrease their appetite because this is the period of which the process of infection by the fungus was taking place. Initially, the conidia sticking on its cuticle or entering through the mouth of the larvae began to show its effect on the 5th day. The process of infection by the conidia through an insect integument usually begins with the conidia sticking to the cuticle, then the conidia ruptures to form germ tubes which grow toward the soft integument to penetrate the cuticle (Fernandes et al. 2007). Infection begins when germ tubes are able to penetrate the insect cuticle and the ability to infect is a determining factor for the fungus virulence (Altre and Vandenberg 2001). After the germ tubes penetrate the cuticle and reach hemocoel, they produce specific infection hyphae originating at appressoria (El-Ghany 2015).

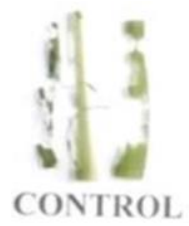

A

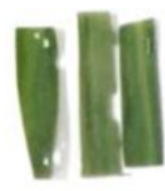

TiCmL.P

$\mathbf{F}$

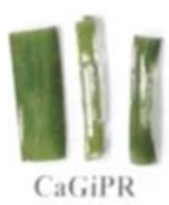

$\mathbf{K}$

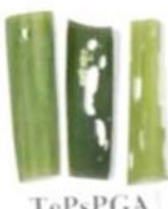

B

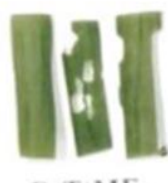

G

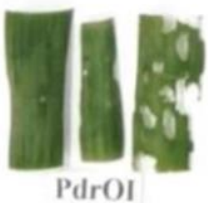

$\mathbf{L}$

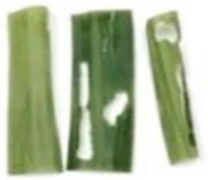

CasPsPGA

C

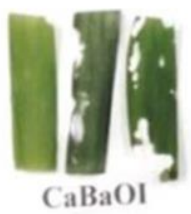

H

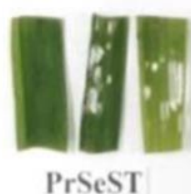

M

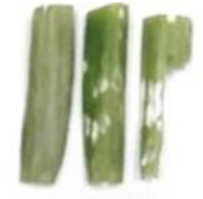

ToBkOI

D

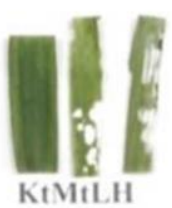

I

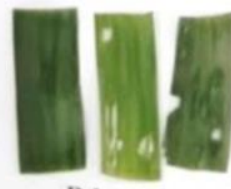

$\mathrm{PdmOI}$

$\mathbf{N}$

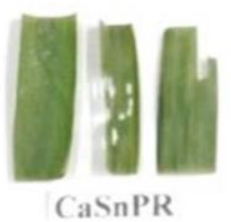

E

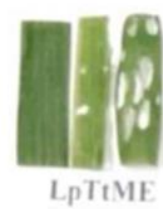

$\mathbf{J}$

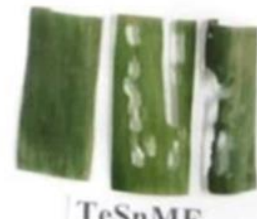

O

Figure 3. The symptoms on maize leaves eaten by Spodoptera frugiperda larvae treated with entomopathogenic fungal isolates with $1 \mathrm{x}$ $10^{6}$ conidia $\mathrm{mL}^{-1}$ : Control (A), TePsPGA (B), CasPsPGA (C), ToBkOI (D), CaSnPR (E), TiCmLpOKI (F), CaTtME (G), CaBkOI (H), KtMtLH (I), LpTtME (J), CaGiPR (K), PirOI (L), PrSeStOI (M), PdmOI (N), dan TeSkME (O)
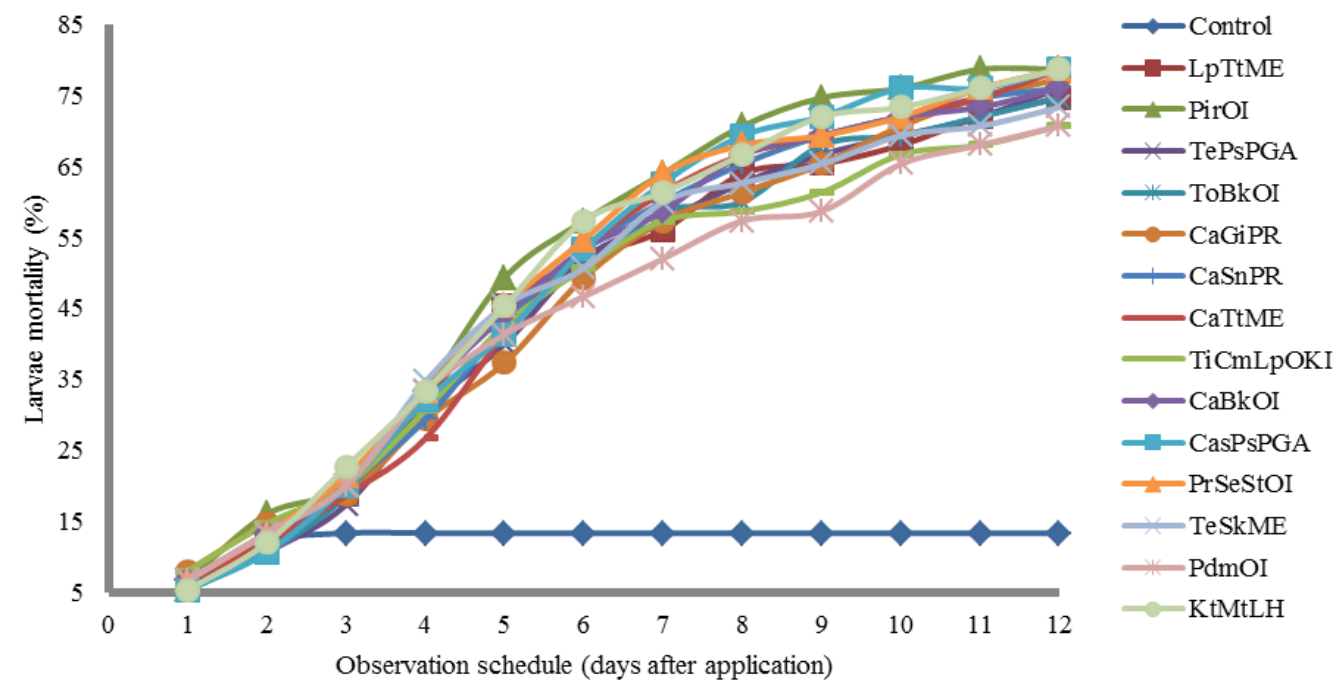

Figure 4. Mortality of Spodoptera frugiperda larvae treated with entomopathogenic fungal isolates with $1 \times 10^{6} \mathrm{conidia}^{-1} \mathrm{on}^{-1}$ observation for 12 days 
Table 6. Mean of larvae mortality, $\mathrm{LT}_{50}$, and $\mathrm{LT}_{95}$ of Spodoptera frugiperda larvae treated with entomopathogenic fungal isolates with $1 \times 10^{6}$ conidia $\mathrm{mL}^{-1}$

\begin{tabular}{lccc}
\hline \multicolumn{1}{c}{ Isolates } & $\begin{array}{c}\text { Mortality } \\
\mathbf{\pm S E}(\boldsymbol{\%})\end{array}$ & $\begin{array}{c}\mathbf{L T}_{\mathbf{5 0}} \\
\mathbf{\pm S E}(\mathbf{d a y s})\end{array}$ & $\begin{array}{c}\text { LT95 } \\
\mathbf{\pm S E}(\text { days })\end{array}$ \\
\hline Control & $13.33 \pm 2.17 \mathrm{a}$ & - & - \\
LpTtME & $74.67 \pm 1.09 \mathrm{~b}$ & $7.23 \pm 0.15$ & $15.12 \pm 0.04$ \\
PirOI & $78.67 \pm 1.09 \mathrm{~b}$ & $6.43 \pm 0.20$ & $14.31 \pm 0.13$ \\
TePsPGA & $76.00 \pm 0.00 \mathrm{~b}$ & $7.14 \pm 0.08$ & $15.01 \pm 0.18$ \\
ToBkOI & $74.67 \pm 2.18 \mathrm{~b}$ & $7.01 \pm 0.30$ & $14.89 \pm 0.41$ \\
CaGiPR & $77.33 \pm 2.88 \mathrm{~b}$ & $7.09 \pm 0.43$ & $14.97 \pm 0.41$ \\
CaSnPR & $76.00 \pm 1.89 \mathrm{~b}$ & $6.98 \pm 0.12$ & $14.86 \pm 0.05$ \\
CaTtME & $78.67 \pm 1.09 \mathrm{~b}$ & $7.10 \pm 0.19$ & $14.98 \pm 0.27$ \\
TiCmLpOKI & $70.67 \pm 2.18 \mathrm{~b}$ & $7.18 \pm 0.16$ & $15.06 \pm 0.24$ \\
CaBkOI & $76.00 \pm 1.89 \mathrm{~b}$ & $6.82 \pm 0.18$ & $14.69 \pm 0.31$ \\
CasPsPGA & $78.67 \pm 1.09 \mathrm{~b}$ & $6.68 \pm 0.32$ & $14.55 \pm 0.44$ \\
PrSeStOI & $78.67 \pm 1.09 \mathrm{~b}$ & $6.53 \pm 0.23$ & $14.40 \pm 0.20$ \\
TeSkME & $73.33 \pm 1.09 \mathrm{~b}$ & $6.93 \pm 0.25$ & $14.81 \pm 0.37$ \\
PdmOI & $70.67 \pm 2.18 \mathrm{~b}$ & $7.54 \pm 0.20$ & $15.41 \pm 0.24$ \\
KtMtLH & $78.67 \pm 2.18 \mathrm{~b}$ & $6.74 \pm 0.40$ & $14.61 \pm 0.38$ \\
F-value & $58.09 *$ & $0.96^{\mathrm{ns}}$ & $0.70^{\mathrm{ns}}$ \\
P-value & 0.00 & 0.51 & 0.74 \\
HSD value & 11.07 & - & - \\
\hline
\end{tabular}

Note: $\mathrm{ns}=$ not significantly different; $*=$ significantly different; values within a column (the data of each isolate) followed by the same letter were not significantly different at $\mathrm{P}<0.05$ according to Tukey's HSD test

Table 7. Mean of percentage of Spodoptera frugiperda pupae formation and adults emerged after their larvae treated with entomopathogenic fungi $1 \times 10^{6}$ conidia $\mathrm{mL}^{-1}$

\begin{tabular}{lcc}
\hline \multicolumn{1}{c}{ Isolates } & $\begin{array}{c}\text { Pupae formation } \\
(\boldsymbol{\%})\end{array}$ & Adults emerged (\%) \\
\hline Control & $86.7 \mathrm{~b}$ & $86.7 \mathrm{~b}$ \\
LpTtME & $25.3 \mathrm{a}$ & $24.0 \mathrm{a}$ \\
PirOI & $21.3 \mathrm{a}$ & $21.3 \mathrm{a}$ \\
TePsPGA & $24.0 \mathrm{a}$ & $21.3 \mathrm{a}$ \\
ToBkOI & $25.3 \mathrm{a}$ & $22.7 \mathrm{a}$ \\
CaGiPR & $22.7 \mathrm{a}$ & $21.3 \mathrm{a}$ \\
CaSnPR & $24.0 \mathrm{a}$ & $21.3 \mathrm{a}$ \\
CaTtME & $21.3 \mathrm{a}$ & $18.7 \mathrm{a}$ \\
TiCmLpOKI & $29.3 \mathrm{a}$ & $28.0 \mathrm{a}$ \\
CaBkOI & $24.0 \mathrm{a}$ & $22.7 \mathrm{a}$ \\
CasPsPGA & $21.3 \mathrm{a}$ & $18.7 \mathrm{a}$ \\
PrSeStOI & $21.3 \mathrm{a}$ & $21.3 \mathrm{a}$ \\
TeSkME & $26.7 \mathrm{a}$ & $18.7 \mathrm{a}$ \\
PdmOI & $29.3 \mathrm{a}$ & $28.0 \mathrm{a}$ \\
KtMtLH & $21.3 \mathrm{a}$ & $20.0 \mathrm{a}$ \\
F-value & $58.09^{*}$ & $69.21^{*}$ \\
P-value & 0.00 & 0.00 \\
HSD value & 11.07 & 10.49 \\
\hline
\end{tabular}

Note: $\mathrm{ns}=$ not significantly different; $*=$ significantly different; values within a column (the data of each isolate) followed by the same letter were not significantly different at $\mathrm{P}<0.05$ according to Tukey's HSD test.

Then, the hyphae spread to the hemolymph and develop to produce blastospores. After that, the blastospores produce secondary metabolites and enzymes, for example, $B$. bassiana produces enzymes of proteolytic and chitinolytic which can disrupt normal cell metabolism

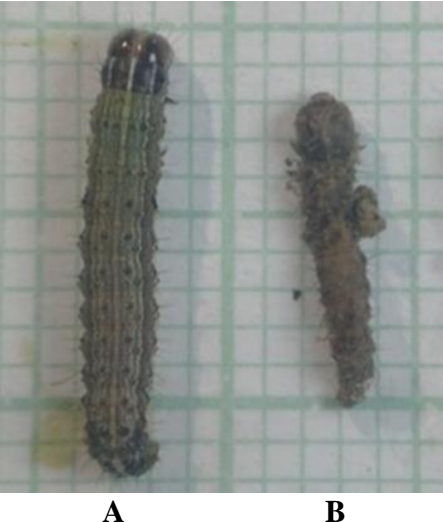

Figure 5. Morphology of Spodoptera frugiperda larvae: healthy larvae of control (A) and dead larvae infected by entomopathogenic fungi (B)

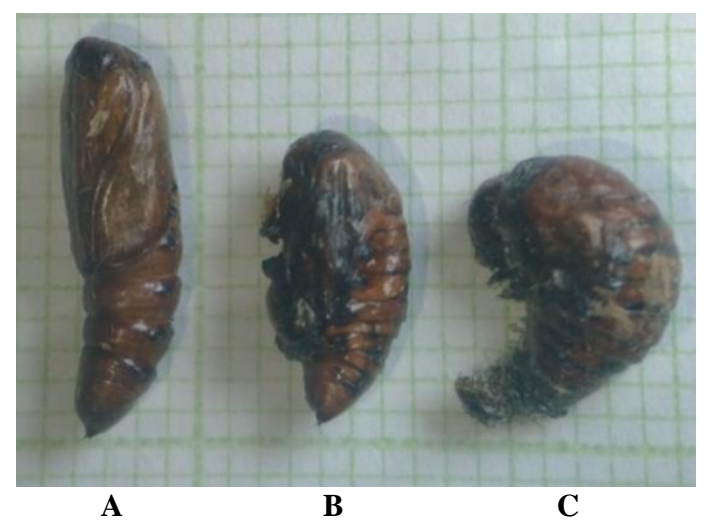

Figure 6. Morphology of Spodoptera frugiperda pupae: healthy pupae of control (A) and unhealthy with malformation pupae infected by entomopathogenic fungi (B and C)

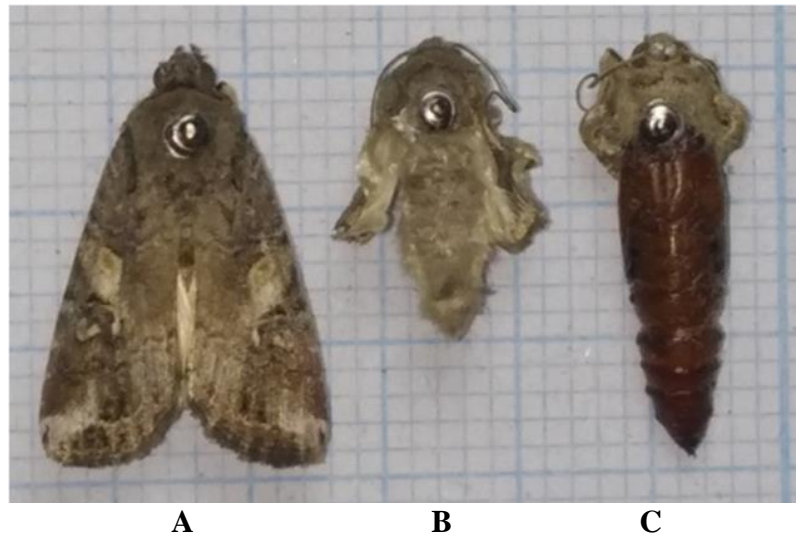

Figure 7. Morphology of Spodoptera frugiperda adults: healthy adults of control (A) and unhealthy with malformation adults infected by entomopathogenic fungi (B and $\mathrm{C}$ )

(Mancillas-Paredes et al. 2019) which is seen from the decreased appetite that ultimately reduces the weight of host insects. The next process, toxins from secondary metabolites begin to kill host insects, but the death of these host insects is not only by the toxin but also due to the 
mechanical damage by fungal penetration into the body of an insect (El-Ghany 2015).

The treated larvae were $78.67 \%$ dead and the surviving larvae were only able to become abnormal pupae and adults and malformations. The larvae that were infected and death caused by the fungi in this study showed the symptoms of his body got dried, shriveled, smaller, and odorless, while the integument was covered by mycelia and conidia resembling yellowish-white flour mixed with dark green similar to the symptoms described by Thaochan and Sausa-Ard (Thaochan and Sausa-Ard 2017). The symptoms of the infected insects due to the entomopathogenic fungal infections vary depending on favorable environmental conditions, for example, relative humidity higher than $62 \%$ (Gutiérrez-Cárdenas et al. 2019), then the mycelia and mature conidia can grow well and cover the entire body of the insect, and the condition of unfavorable mycelia and conidia does not appear (El-Ghany 2015). Metarhizium had been reported to be effective against Aphis craccivora (Mweke et al. 2019), Spodoptera litura (Gustianingtyas et al. 2020), and Sitophilus oryzae (Kavallieratos et al. 2015).

Pupae getting unhealthy due to the treatment with Metarhizium sp. are abnormal and malformation and unable to become adults, while those that can become adults generally have folded wings and a smaller body than those of the healthy ones. Abnormal and malformation of insects because of the infectious entomopathogenic fungi result from the activity of proteases and chitinases that dissolve protein and chitin in the body of the insects (Mancillas-Paredes et al. 2019). The abnormal adults with folded wings could not continue their offspring because they were not able to fly for having the mating which automatically can reduce the population of the offspring. In line with the research of Kalvnadi et al. (2018), the entomopathogenic fungi can also disrupt insect normal growth, reduce fecundity, and generate fitness.

From the results of this study, it can be concluded that the found entomopathogenic fungi all generate from Genus, Metarhizium and all isolates are pathogenic to $S$. frugiperda larvae (70.67-78.67\%), the two most pathogenic isolates (PirOI and CasPsPGA) caused 78.67\% of the mortality and significantly suppressed the emergence of adults up to $81.2 \%$. The most pathogenic isolates found from the lowlands (PirOI) and highlands (CasPsPGA) of South Sumatra both have the potential to be developed into local-specific mycoinsecticides to control pest insects in the highlands and/or lowlands in Indonesia.

\section{ACKNOWLEDGEMENTS}

This research was funded by the Directorate of Research and Community Service (DRPM), Deputy for Research and Development Strengthening, Ministry of Research and Technology/National Research and Innovation Agency, Fiscal Year 2020 in accordance with the Basic Research (Penelitian Dasar) contract number: 170/SP2H/LT/DRPM/2020, which was chaired by SH.

\section{REFERENCES}

Akutse KS, Kimemia JW, Ekesi S, Khamis FM, Ombura OL, Subramanian S. 2019. Ovicidal effects of entomopathogenic fungal isolates on the invasive fall armyworm Spodoptera frugiperda (Lepidoptera: Noctuidae). J Appl Entomol 143: 626-634. DOI: 10.1111/jen.12634.

Altre JA, Vandenberg JD. 2001. Factors influencing the infectivity of isolates of Paecilomyces fumosoroseus against diamondback moth, Plutella xylostella. J Invertebr Pathol 78: 31-36. DOI: 10.1006/jipa.2001.5043.

Anwar W, Khan SN, Aslam M, Haider MS, Shahid AA, Ali M. 2015. Exploring fungal flora associated with insects of cotton agroecological zones of Punjab, Pakistan. Pakistan Entomologist 37: 27-31.

Ayudya DR, Herlinda S, Suwandi S. 2019. Insecticidal activity of culture filtrates from liquid medium of Beauveria bassiana isolates from South Sumatra (Indonesia) wetland soil against larvae of Spodoptera litura. Biodiversitas 20: 2101-2109. DOI: 10.13057/biodiv/d200802.

Chen WH, Han YF, Liang JD, Liang ZQ. 2019. Morphological and phylogenetic characterization of novel Metarhizium species in Guizhou, China. Phytotaxa 419: 189-196. DOI:10.11646/phytotaxa.419.2.5.

Chen Z, Xu L, Yang F, Ji G, Yang J, Wang J. 2014. Efficacy of Metarhizium anisopliae isolates MAX-2 from Shangri-la, China under desiccation stress. BMC Microbiology 14: 1-8. DOI: 14712180/14/4.

Early R, González-Moreno P, Murphy ST, Day R. 2018. Forecasting the global extent of invasion of the cereal pest Spodoptera frugiperda, the fall armyworm. NeoBiota 40: 25-50. DOI:10871/34861.

El-Ghany TMA. 2015. Entomopathogenic Fungi and their Role in Biological Control. Biology Department Faculty of Science, Jazan University KSA, Cairo. DOI: 10.4172/978-1-63278-065-2-66.

Fernandes EKK, Rangel DEN, Moraes AM., Bittencourt VREP, Roberts DW. 2007. Variability intolerance to UV-B radiation among Beauveria spp. isolates. J Invertebr Pathol 96: 237-243. DOI: 10.1016/j.jip.2007.05.007

Ganiger PC, Yeshwanth HM, Muralimohan K, Vinay N, Kumar ARV, Chandrashekara K. 2018. Occurrence of the new invasive pest, fall armyworm, Spodoptera frugiperda (J.E. Smith) (Lepidoptera: Noctuidae), in the maize fields of Karnataka, India. Current Science 115: 621-623.

Goergen G, Kumar PL, Sankung SB, Togola A, Tam M. 2016. First report of outbreaks of the fall armyworm Spodoptera frugiperda (J E Smith) (Lepidoptera, Noctuidae), a new alien invasive pest in West and Central Africa. PLoS One 11: 1-9. DOI: 10.1371/journal.pone.0165632

De Groote H, Kimenju SC, Munyua B, Palmas S, Kassie M, Bruce A. 2020. Spread and impact of fall armyworm (Spodoptera frugiperda J.E. Smith) in maize production areas of Kenya. Agriculture, $\begin{array}{llr}\text { Ecosystems } & \text { and } & \text { Environment }\end{array}$ DOI:10.1016/j.agee.2019.106804.

Gustianingtyas M, Herlinda S, Suwandi, Suparman, Hamidson H, Hasbi, Setiawan A, Verawaty M, Elfita, Arsi. 2020.Toxicity of entomopathogenic fungal culture filtrate of lowland and highland soil of South Sumatra (Indonesia) against Spodoptera litura larvae. Biodiversitas 21 (5): 1839-1849. DOI: 10.13057/biodiv/d210510.

Gutiérrez-Cárdenas OG, Cortez-Madrigal H, Malo EA, Gómez-Ruíz J, Nord R. 2019. Physiological and pathogenical characterization of Beauveria bassiana and Metarhizium anisopliae isolates for management of adult Spodoptera frugiperda. Southwestern Entomologist 44: 409-421. DOI: 10.3958/059.044.0206

Harrison RD, Thierfelder C, Baudron F, Chinwada P, Midega C, Scha U, Berg J Van Den. 2019. Agro-ecological options for fall armyworm (Spodoptera frugiperda JE Smith) management: Providing low-cost, smallholder friendly solutions to an invasive pest. J Environ Manag 243: 318-330. DOI: 10.1016/j.jenvman.2019.05.011

Hernandez-Trejo A, Estrada-Drouaillet B, López-Santillán J, RiosVelasco C, Varela-Fuentes S, Rodríguez-Herrera R, OsorioHernández E. 2019. In vitro evaluation of native entomopathogenic fungi and neem (Azadiractha indica) extracts on Spodoptera frugiperda. Intl J Exp Bot 4: 75-84. DOI: 1037//0033-2909.I26.1.78.

Humber RA. 2005. Entomopathogenic Fungal Identification. USDA-ARS Plant Protection Research Unit, Ithaca. 
IPPC. 2019. The Occurrence of Fall Armyworm (Spodoptera frugiperda) in Indonesia. IPPC (International Plant Protection Convention) Official Pest Report, No. IDN-04/1. FAO, Rome, Italy. https://www.ippc.int/. [Report]

Kalvnadi E, Mirmoayedi A, Alizadeh M, Pourian HR. 2018. Sub-lethal concentrations of the entomopathogenic fungus, Beauveria bassiana increase fitness costs of Helicoverpa armigera (Lepidoptera: Noctuidae) offspring. J Invertebrate Pathol 158: 32-42. DOI: 10.1016/j.jip.2018.08.012.

Kavallieratos NG, Athanassiou GG, Kontodimas MM, Aountala K, Demetrius C. 2015. Evaluation of the entomopathogenic fung Beauveria bassiana, Metarhizium anisopliae, and Isaria fumosorosea for control of Sitophilus oryzae. J. Food Protection 77(1): 87-93.

Karthikeyan A, Shanthi V, Nagasathya A. 2008. Effect of different media and $\mathrm{pH}$ on the growth of Beauveria bassiana and its parasitism on leaf-eating caterpillars. Res J Agric Biol Sci 4: 117-119.

Kumela T, Simiyu J, Sisay B, Likhayo P, Gohole L, Tefera T. 2018. Farmers knowledge, perceptions, and management practices of the new invasive pest, fall armyworm (Spodoptera frugiperda) in Ethiopia and Kenya. Intl J Pest Manag 65: 1-9. DOI: 10.1080/09670874.2017.1423129

Lestari P, Budiarti A, Fitriana Y, Susilo FX, Swibawa IG. 2020. Identification and genetic diversity of Spodoptera frugiperda in Lampung Province, Indonesia. Biodiversitas 21: 1670-1677. DOI: 10.13057/biodiv/d210448.

Lopes RB, Souza DA, Rocha LFN, Montalva C, Luz C, Humber RA, Faria M. 2018. Metarhizium alvesii sp. nov.: A new member of the Metarhizium anisopliae species complex. J Invertebr Pathol 151: 165168. DOI: 10.1016/j.jip.2017.12.001.

Machado BB, Orue JPM, Arruda MS, Santos C V., Sarath DS, Goncalves WN, Silva GG, Pistori H, Roel AR, Rodrigues-Jr JF. 2016. BioLeaf: A professional mobile application to measure foliar damage caused by insect herbivory. Comput Electr Agric 129: 44-55. DOI: 10.1016/j.compag.2016.09.007

Mancillas-Paredes J., Hernández-Sánchez H, Jaramillo-Flores ME, García-Gutiérrez C. 2019. Proteases and chitinases induced in Beauveria bassiana during infection by Zabrotes subfasciatus. Southwestern Entomol 44: 125-137. DOI: 10.3958/059.044.0114.

Montezano DG, Specht A, Sosa-gómez DR, Brasília UD. 2018. Host plants of Spodoptera frugiperda (Lepidoptera: Noctuidae) in the Americas. Afr Entomol 26: 286-300. DOI: 10.4001/003.026.0286

Mweke A, Akutse KS, Ulrichs C, Fiaboe KKM, Maniania NK, Ekesi S. 2019. Efficacy of aqueous and oil formulations of a specific Metarhizium anisopliae isolate against Aphis craccivora Koch, 1854 (Hemiptera: Aphididae) under field conditions. J Appl Entomol. 143(10): 1182-1192.

Nagoshi RN, Fleischer S, Meagher RL, Hay-roe M, Silvie P, Vergara C, Westbrook J, Khan A, Muru MG, Silvie P, Vergara C, Westbrook J. 2017. Fall armyworm migration across the Lesser Antilles and the potential for genetic exchanges between North and South American populations. PLoS One 12: 1-18. DOI 10.1371/journal.pone.0171743.

Nboyine JA, Kusi F, Abudulai M, Badii BK, Zakaria M, Adu GB, Haruna A, Seidu A, Osei V, Alhassan S, Yahaya A. 2020. A new pest Spodoptera frugiperda (J.E. Smith), in tropical Africa: Its seasonal dynamics and damage in maize fields in northern Ghana. Crop Protect 127: 1-7. DOI: 10.1016/j.cropro.2019.104960.

Ngangambe MH, Mwatawala MW. 2020. Effects of entomopathogenic fungi (EPFs) and cropping systems on parasitoids of fall armyworm (Spodoptera frugiperda) on maize in eastern central, Tanzania Biocontrol Sci Technol 30: 1-13. $\quad$ DOI: 10.1080/09583157.2020.1726878.
Otim MH, Tay WT, Walsh TK, Kanyesigye D, Adumo S, Abongosi J, Ochen S, Sserumaga J, Alibu S, Abalo G, Asea G, Agona A. 2018. Detection of sister-species in invasive populations of the fall armyworm Spodoptera frugiperda (Lepidoptera: Noctuidae) from Uganda. PLoS One 13: 1-18. DOI: 10.1371/journal.pone.0194571

Prabawati G, Herlinda S, Pujiastuti Y. 2019. The abundance of canopy arthropods in South Sumatra (Indonesia) freshwater swamp main and ratooned rice applied with bioinsecticides and synthetic insecticide. Biodiversitas 20: 2921-2930. DOI: 10.13057/biodiv/d201021.

Ramos Y, Taibo AD, Jiménez JA, Portal O. 2020. Endophytic establishment of Beauveria bassiana and Metarhizium anisopliae in maize plants and its effect against Spodoptera frugiperda (J. E. Smith) (Lepidoptera: Noctuidae) larvae. Egyptian J Biol Pest Control 30: 1-6. DOI: 10.1186/s41938-020-00223-2.

Rivero-Borja M, Guzmán-Franco AW, Rodríguez-Leyva E, SantillánOrtega C, Pérez-Panduro A. 2018. Interaction of Beauveria bassiana and Metarhizium anisopliae with chlorpyrifos ethyl and spinosad in Spodoptera frugiperda larvae. Pest Manag Sci 74: 2047-2052. DOI: $10.1002 / p s .4884$

Safitri A, Herlinda S, Setiawan A. 2018. Entomopathogenic fungi of soils of freshwater swamps, tidal lowlands, peatlands, and highlands of South Sumatra, Indonesia. Biodiversitas 19: 2365-2373. DOI: 10.13057/biodiv/d190647

Sharma L, Oliveira I, Torres L, Marques G. 2018. Entomopathogenic fungi in Portuguese vineyards soils: suggesting a 'Galleria-Tenebriobait method' as bait-insects Galleria and Tenebrio significantly underestimate the respective recoveries of Metarhizium (robertsii) and Beauveria (bassiana). MycoKeys 23: 1-23. DOI: 10.3897/mycokeys.38.26970.

Shylesha AN, Jalali SK, Gupta A, Varshney R, Venkatesan T. 2018. Studies on new invasive pest Spodoptera frugiperda (J .E . Smith) (Lepidoptera: Noctuidae) and its natural enemies. J Biol Control 32: 145-151. DOI: $10.18311 / \mathrm{jbc} / 2018 / 21707$

Souza ML, Sanches MM, Souza DA de, Faria M, Espinel-Correal C, Sihler W, Lopes RB. 2019. Within-host interactions of Metarhizium rileyi strains and nucleopolyhedroviruses in Spodoptera frugiperda and Anticarsia gemmatalis (Lepidoptera: Noctuidae). J Invertebr Pathol 162: 10-18. DOI: 10.1016/j.jip.2019.01.006.

Sumikarsih E, Herlinda S, Pujiastuti Y. 2019. Conidial density and viability of Beauveria bassiana isolate from Java and Sumatra and their virulence against Nilaparvata lugens at different temperatures. Agrivita 41: 335-349. DOI: 10.17503/agrivita.v41i2.2105

Thaochan N, Sausa-Ard W. 2017. Occurrence and effectiveness of indigenous Metarhizium anisopliae against adults Zeugodacus cucurbitae (Coquillett) (Diptera: Tephritidae) in Southern Thailand. Songklanakarin J Sci Tech 39: 325-334. DOI:10.14456/sjstpsu.2017.35.

Wilson WM, Ibarra JE, Oropeza A, Hernández MA, Toledo-Hernández RA, Toledo J. 2020. Infection of Anastrepha ludens (Diptera: Tephritidae) adults during emergence from soil treated with Beauveria bassiana under various texture, humidity, and temperature conditions. Florida Entomol 100: 503-508. DOI: $10.1653 / 024.100 .0302$.

Wu X, Zhang L, Yang C, Zong M, Huang Q, Tao L. 2016. Detection on emamectin benzoate-induced apoptosis and DNA damage in Spodoptera frugiperda Sf-9 cell line. Pestic Biochem Physiol 126: 612. DOI: $10.1016 /$ j.pestbp.2015.06.009

Yang M, Wang B, Gao J, Zhang Y, Xu W, Tao L. 2017. Chemosphere spinosad induces programmed cell death involves mitochondrial dysfunction and cytochrome $\mathrm{C}$ release in Spodoptera frugiperda Sf9 cells. Chemosphere 169: 155-61. DOI: 10.1016/j.chemosphere.2016.11.065. 